\title{
Host susceptibility to Gonipterus platensis (Coleoptera: Curculionidae) of Eucalyptus species
}

\author{
Catarina I. Gonçalves ${ }^{1}$ (D) $\cdot$ Liliana Vilas-Boas ${ }^{2} \cdot$ Manuela Branco $^{2} \cdot$ Gabriel D. Rezende $^{1} \cdot$ Carlos Valente $^{1}$
}

Received: 3 December 2018 / Accepted: 9 June 2019 / Published online: 20 June 2019

(C) INRA and Springer-Verlag France SAS, part of Springer Nature 2019

\begin{abstract}
- Key message Gonipterus platensis is an important insect pest of eucalypt plantations. Despite biological control by the egg parasitoid Anaphes nitens, economic losses remain high in several areas outside its native range where susceptible eucalypt species are grown in commercial plantations. The susceptibility to G. platensis of 17 Eucalyptus species was evaluated and possible alternatives for reforestation in high pest incidence areas were identified.

- Context Gonipterus platensis is an important pest of Eucalyptus worldwide. Despite biological control, it causes significant losses to Eucalyptus plantations in several areas, requiring alternative management options.

- Aims We analysed host preference of G. platensis towards 17 Eucalyptus species to identify less susceptible plant materials that could be used in areas of high pest incidence.

- Methods Feeding damage was assessed in field trials in three consecutive years. No-choice and choice tests were conducted with Eucalyptus species of contrasting susceptibility.

- Results Within subgenus Symphyomyrtus, all species from section Maidenaria were used by G. platensis for feeding. Within this section, E. globulus was always the preferred species, while E. nitens was the least preferred. Differences in susceptibility were less pronounced at high attack intensity by G. platensis. Eucalyptus saligna (section Latoangulatae) was the least preferred species among Symphyomyrtus. All species from subgenus Eucalyptus had low susceptibility to G. platensis, particularly E. regnans, which was never attacked under field conditions. The results were confirmed by choice and no-choice laboratory and semi-field tests.

- Conclusion Significant differences in susceptibility to G. platensis were found between the 17 Eucalyptus species tested, which could be explored for reforestation with less susceptible plant materials.
\end{abstract}

Keywords Tree susceptibility $\cdot$ Defoliation $\cdot$ Eucalyptus snout beetle $\cdot$ Reforestation

\section{Introduction}

Handling Editor: Aurélien Sallé

Contributions of the co-authors Conceptualization and experimental design: CV, GDR, CIG, MB, LVB; Field and laboratory work: LVB, CIG; Data analysis: LVB, MB, CIG; Manuscript writing: CIG, LVB; Manuscript reviewing and editing: $\mathrm{MB}, \mathrm{CV}$, GDR; Project Administration: GDR, MB, CV; Funding acquisition: GDR, MB, CV.

Catarina I. Gonçalves

catarina.goncalves@thenavigatorcompany.com

1 RAIZ - Instituto de Investigação da Floresta e Papel, Quinta de São Francisco, Apartado 15, 3801-501 Eixo-Aveiro, Portugal

2 Centro de Estudos Florestais, Instituto Superior de Agronomia, Universidade de Lisboa, Tapada da Ajuda,

1349-017 Lisbon, Portugal
Eucalypts (Eucalyptus L'Hér., Myrtaceae) are among the most used tree species in plantations worldwide, primarily because of their fast growth and adaptability to environmental conditions (Campinhos 1999; Wingfield et al. 2008). In Europe, eucalypts are mainly cultivated in Portugal and Spain for the pulp and paper industry, with an overall area of roughly 810,000 ha in Portugal (ICNF 2013) and 630,000 ha in Spain (SECF 2010). Eucalyptus globulus Labill. is the most planted species in these two countries because of its high quality for pulping (Costa e Silva et al. 2009; GonzálezGarcía et al. 2009). Eucalyptus snout beetles, Gonipterus spp. (Coleoptera: Curculionidae), are among the most severe pests of Eucalyptus. Gonipterus platensis Marelli in particular is the most widespread species found outside Australia 
(Mapondera et al. 2012). This pest is present in New Zealand, eastern and western South America, southwestern North America, and southwestern Europe (Mapondera et al. 2012).

Soon after its detection in Spain in 1991, G. platensis became the most serious pest of E. globulus plantations in Galicia (Spain) and northern Portugal (Mansilla-Vázquez and Pérez-Otero 1996; Sousa and Ferreira 1996). The snout beetle feeds on eucalypt leaves, with marked preference for growing shoots with developing leaves, for both feeding and oviposition. Adults will preferably feed along the edges of leaves but they will also feed on the soft bark of fresh shoots during periods of heavy infestation. The larvae, which cause most damage, feed on the entire leaf lamina, leaving only the harder fibres (Loch 2006; Tooke 1955). Severe and repeated defoliation can lead to thinning of the upper crown or 'broomtopping', reduced growth, tree deformation, and tree decline (Echeverri-Molina and Santolamazza-Carbone 2010; Loch 2006; Loch and Matsuki 2010; Tooke 1955). Biological control was one of the first strategies used to control G. platensis. The Australian egg parasitoid Anaphes nitens Girault (Hymenoptera: Mymaridae) has been introduced into all continents where the snout beetle is present, with good results (Arzone 1985; Cordero-Rivera et al. 1999; Hanks et al. 2000; Lanfranco and Dungey 2001; Tribe 2005). However, the parasitoid has not been efficient in reducing the damage caused by $G$. platensis below economically sustainable levels in several regions, in particular in cooler regions of countries such as Portugal, Spain, or Chile (Cordero-Rivera et al. 1999; Lanfranco et al. 2011; Reis et al. 2012; Valente et al. 2018). In Portugal, reductions in wood volume are estimated to be as high as $86 \%$ in high altitude regions where parasitism rates by A. nitens are low during winter and early spring (Reis et al. 2012), resulting in estimated losses of 648 million euros over a 20-year period (Valente et al. 2018).

Faced with significant economic losses, stakeholders are searching for alternative management strategies, such as biological control with alternative natural enemies or using eucalypt species that are less susceptible to G. platensis (Jactel et al. 2009; Richardson and Meakins 1986; Valente et al. 2017). Although several authors have focussed on host susceptibility to Gonipterus spp., such studies often dealt with distinct species within the snout beetle complex (Mapondera et al. 2012), resulting in discrepancies in literature (Newete et al. 2011). In countries where G. platensis is present, E. globulus is consistently found to be a preferred host, even though several other species have also been identified as susceptible, such as Eucalyptus camaldulensis Dehnh., E. grandis W.Hill, E. longifolia Link, E. obliqua L'Hér., E. propinqua Deane \& Maiden, E. robusta Sm., and E. viminalis Labill. (Cordero-Rivera and Santolamazza-Carbone 2000; Hanks et al. 2000; Huerta-Fuentes et al. 2008; Lanfranco and Dungey 2001).
In the present study, we analysed the susceptibility of 17 Eucalyptus species to G. platensis, including E. globulus, in order to identify potential alternative species for reforestation in the areas most affected by the pest. Because these areas are mostly located in cool high altitude regions, the Eucalyptus species were pre-selected for their ability to withstand low temperatures. Host plant susceptibility to G. platensis was tested under field conditions by evaluating naturally occurring defoliation and insect abundance in field trials for 3 years. In addition, no-choice and choice tests with selected Eucalyptus species of contrasting susceptibility were conducted under semi-field and laboratory conditions.

\section{Material and methods}

\subsection{Study sites and plant materials}

Sixteen alternate Eucalyptus species to E. globulus were preselected for their adaptation to low temperatures. The seeds were obtained from CSIRO (Commonwealth Scientific and Industrial Research Organization, Australia). One to three provenances of each species were used (Table 1) to assure that each species was well represented. One seedling provenance and four commercial clones of E. globulus were also used, totalling 47 distinct provenances. All plants were produced in RAIZ and Viveiros Aliança nurseries (Pegões, Portugal). Field studies were conducted in three trials in Portugal, located in Carregal do Sal, hereafter Carregal (40 47' 00" N, $8^{\circ} 04^{\prime}$ $\left.30^{\prime \prime} \mathrm{W}\right)$, Pampilhosa da Serra, hereafter Pampilhosa $\left(40^{\circ} 06^{\prime}\right.$ $30^{\prime \prime} \mathrm{N}, 7^{\circ} 47^{\prime} 38^{\prime \prime} \mathrm{W}$ ), and Arouca (40 $58^{\prime} 04^{\prime \prime} \mathrm{N}, 8^{\circ} 07^{\prime} 14^{\prime \prime}$ W), planted in May 2010, October 2010, and April 2011, respectively. Seventeen species were planted in Carregal (47 provenances) and Pampilhosa (45 provenances), and fifteen species were used in Arouca (39 provenances), due to lower plant availability for later trials. In each trial, eight randomized blocks consisting of five plants of each provenance were used (1880, 1800, and 1375 plants per trial in Carregal, Pampilhosa, and Arouca, respectively). The number of plants available for the evaluation of $G$. platensis defoliation was variable due to mortality in the months following planting. For the purpose of evaluating susceptibility to the pest, all provenances of a single species were used in the analyses.

\subsection{Field trial evaluation}

The level of defoliation caused by $G$. platensis feeding by both adults and larvae was evaluated after spring feeding (between July and November in 2012, 2013, and 2014) in the Arouca and Pampilhosa trials. The snout beetle was not detected in Carregal in any year. Defoliation was evaluated by visual estimate of the leaf area consumed by $G$. platensis larvae and adults in recent foliage, in the upper third of the crown 
Table 1 Eucalypt species and provenances used in field trials (ACT, Australian Capital Territory; AUS, Australia; BR, Brazil; NSW, New South Wales; $P T$, Portugal; $Q L D$, Queensland; $S A$, South Africa; TAS, Tasmania; VIC, Victoria)

\begin{tabular}{|c|c|c|c|c|}
\hline Subgenus ${ }^{1}$ & Section $^{2}$ & Series $^{2}$ & Species & Provenance \\
\hline \multirow[t]{13}{*}{ Eucalyptus } & \multirow[t]{7}{*}{ Cineraceae } & \multirow[t]{7}{*}{ Fraxinales } & \multirow[t]{3}{*}{ Eucalyptus delegatensis R.T.Baker } & Rubicon, VIC (AUS) \\
\hline & & & & Mount Ewen Dargo-Bright, VIC (AUS) \\
\hline & & & & Bulls Head, ACT (AUS) \\
\hline & & & \multirow[t]{3}{*}{ Eucalyptus fraxinoides H.Deane \& Maiden } & Southeast of Canberra, NSW (AUS) \\
\hline & & & & Nimmitabel, NSW (AUS) \\
\hline & & & & Badja, NSW (AUS) \\
\hline & & & Eucalyptus oreades R.T.Baker & Newnes State Forest, Lithgow, NSW (AUS) \\
\hline & \multirow[t]{6}{*}{ Eucalyptus } & \multirow[t]{6}{*}{ Regnantes } & \multirow[t]{3}{*}{ Eucalyptus fastigata H.Deane and Maiden } & Tallaganda State Forest, NSW (AUS) \\
\hline & & & & Brown Mountain Nimmitabel, NSW (AUS) \\
\hline & & & & Errinundra Plateau, VIC (AUS) \\
\hline & & & \multirow[t]{3}{*}{ Eucalyptus regnans F.Muell. } & Lisle, TAS (AUS) \\
\hline & & & & Traralgon, VIC (AUS) \\
\hline & & & & Moogara, TAS (AUS) \\
\hline \multirow[t]{31}{*}{ Symphyomyrtus } & \multirow[t]{3}{*}{ Latoangulatae } & \multirow[t]{3}{*}{ Transversae } & \multirow[t]{3}{*}{ Eucalyptus saligna $\mathrm{Sm}}$. & Blackdown Tableland, QLD (AUS) \\
\hline & & & & Styx River SF339, NSW (AUS) \\
\hline & & & & Richmond Range, NSW (AUS) \\
\hline & \multirow[t]{28}{*}{ Maidenaria } & \multirow[t]{2}{*}{ Benthamianae } & \multirow[t]{2}{*}{ Eucalyptus benthamii Maiden \& Cambage } & SSO Crossley, NSW (AUS) \\
\hline & & & & Embrapa Florestas, Paraná (BR) \\
\hline & & \multirow[t]{3}{*}{ Bridgesianae } & \multirow[t]{3}{*}{ Eucalyptus dunnii Maiden } & Wallaby Creek, NSW (AUS) \\
\hline & & & & Boomi Creek, NSW (AUS) \\
\hline & & & & CSO Southern NSW (AUS) \\
\hline & & \multirow[t]{6}{*}{ Compactae } & \multirow[t]{3}{*}{ Eucalyptus badjensis Beuzev. \& M.B.Welch } & Glenbog, NSW (AUS) \\
\hline & & & & Brown Mountain, NSW (AUS) \\
\hline & & & & Deua National Park, NSW (AUS) \\
\hline & & & \multirow[t]{3}{*}{ Eucalyptus smithii R.T.Baker } & Tallaganda State Forest, NSW (AUS) \\
\hline & & & & Wingello State Forest, NSW (AUS) \\
\hline & & & & Mount Dromedary, NSW (AUS) \\
\hline & & \multirow[t]{3}{*}{ Foveolatae } & \multirow[t]{3}{*}{ Eucalyptus macarthurii H.Deane \& Maiden } & Pietermaritzburg (SA) \\
\hline & & & & Long Swamp Creek, NSW (AUS) \\
\hline & & & & Paddys River, NSW (AUS) \\
\hline & & \multirow[t]{10}{*}{ Globulares } & Eucalyptus bicostata Maiden, Blakely \& Simmonds & Narrow Neck, NSW (AUS) \\
\hline & & & & Wee Jasper, NSW (AUS) \\
\hline & & & & Nullo Mountain State Forest, NSW (AUS) \\
\hline & & & Eucalyptus globulus Labill. & 4 clones and 1 seedlot, Viveiros Aliança (PT) \\
\hline & & & Eucalyptus maidenii F.Muell. & Yambulla State Forest, NSW (AUS) \\
\hline & & & & Myrtle Mountain, NSW (AUS) \\
\hline & & & & Monga, NSW (AUS) \\
\hline & & & Eucalyptus nitens Maiden & Blue Range Road, VIC (AUS) \\
\hline & & & & Tallaganda State Forest, NSW (AUS) \\
\hline & & & & Ebor, NSW (AUS) \\
\hline & & Viminales & Eucalyptus dalrympleana Maiden & Mount Canobolas Orange, NSW (AUS) \\
\hline & & & Eucalyptus viminalis Labill. & Otway, VIC (AUS) \\
\hline & & & & Canobolas State Forest, NSW (AUS) \\
\hline & & & & Glenbog State Forest, NSW (AUS) \\
\hline
\end{tabular}

\footnotetext{
${ }^{1}$ Sensu Hill and Johnson (1995)
}

${ }^{2}$ Sensu Brooker (2000) 
where insect feeding is strongly concentrated. Tree height (on average $6.7 \mathrm{~m}$ in 2014) was an impediment to the use of a more classical Crown Damage Index (e.g. Stone et al. 2003, developed for young eucalypt plantations), and therefore defoliation intensity was assessed using the following classes: 1 (no evidence of insect feeding); 2 ( $<25 \%$ of the leaves with evidence of insect feeding); 3 (25-50\% of the leaves with evidence of insect feeding); 4 (50-75\% of the leaves with evidence of insect feeding); 5 (>75\% of the leaves with evidence of insect feeding and at least one fourth of the leaves having more than $50 \%$ of their area intact); 6 (>75\% of the leaves with evidence of insect feeding and less than one fourth of the leaves having more than $50 \%$ of their area intact); and 7 ( $100 \%$ defoliation). Mean defoliation class values were then assigned to each sampled tree as follows: $1(0 \%) ; 2(12.5 \%) ; 3$ (37.5\%); 4 (62.5\%); 5 (81.3\%); 6 (93.5\%); and $7(100 \%)$. Because some of the eucalypt species tested are heteroblastic, i.e. they produce juvenile foliage early in their development, which is replaced by morphologically and physiologically distinct adult foliage (Gosney et al. 2014; Steinbauer 2002), the presence of juvenile foliage in the upper third of the crown was recorded for each tree in 2012 and 2013. Trees were classified as having fully transitioned to adult foliage or as retaining juvenile foliage (totally or partially).

The abundance of G. platensis was evaluated in May and June 2012, in Pampilhosa and Arouca trials, respectively. Five trees (1.5 to $2.0 \mathrm{~m}$ in height) of each Eucalyptus provenance were selected and the number of snout beetle adults, larvae, and egg capsules was visually estimated in the canopy according to the following categories: 0 (no insects); 1 (1-10 insects); 2 (11-20 insects); and 3 (more than 20 insects).

During field evaluations, the presence of biological agents other than the snout beetle was recorded, but neither was found to reach damaging levels.

\subsection{No-choice and choice tests}

Adults of $G$. platensis were collected from an infested E. globulus stand near São Pedro do Sul $\left(40^{\circ} 47^{\prime} 00^{\prime \prime} \mathrm{N}, 8^{\circ}\right.$ $04^{\prime} 30^{\prime \prime} \mathrm{W}$ ) and taken to RAIZ laboratory where they were weighed and sorted by sex.

No-choice tests were performed at the Carregal field trial site, as no $G$. platensis adults or larvae were present in this location. Five eucalypt species were selected based on differences in susceptibility to G. platensis observed at the Arouca and Pampilhosa trials, namely E. globulus, E. badjensis Beuzev. \& M.B.Welch, E. smithii R.T.Baker, E. nitens Maiden, and E. regnans F.Muell.. Branches with similar length and number of newly expanded adult leaves were enclosed in $1 \times 1-\mathrm{mm}$ mesh sleeves $(55 \mathrm{~cm}$ in length $\times$ $18 \mathrm{~cm}$ in diameter). One sleeve was placed in each of ten trees per eucalypt species. For each eucalypt species, trees of similar size in at least two different blocks were selected. Eight randomly selected and previously weighed $G$. platensis adults (four males and four females) were placed inside each sleeve in March 2013. Insect weight at the beginning of the trial was confirmed not to differ between eucalypt species (Wald $\chi^{2}=$ $1.6 ; \mathrm{df}=4 ; p=0.803)$. One month later, the snout beetles were removed, counted, and transferred to a new branch of the same tree. At the end of each month, the sleeved branches were removed and taken to the laboratory where their leaves were scanned. The leaf area consumed by $G$. platensis adults was then determined using Image J version 1.48 software (National Institute of Health, Bethesda, MD, U.S.A.). Total leaf area lost due to feeding was estimated by adding the area consumed in both periods. The surviving adult snout beetles were counted and weighed.

Choice tests were performed in the forest entomology laboratory in Instituto Superior de Agronomia (University of Lisbon). Three Eucalyptus species with contrasting susceptibility were selected, based on field experiments, namely E. globulus (high susceptibility), E. nitens (moderate susceptibility), and E. regnans (low susceptibility). Three host combinations were used: E. globulus vs E. nitens, E. globulus vs $E$. regnans, and $E$. nitens vs $E$. regnans. Trials were performed in a cylindrical see-through cage $(60 \mathrm{~cm}$ length $\times 25 \mathrm{~cm}$ diameter) closed with a net at the top to allow airflow. Ca. $15 \mathrm{~cm}$ long branches with newly expanded adult leaves were collected from trees in the Carregal trial. For each species combination, one branch of each host species was placed on opposite sides of the cage. Branches were inserted in water soaked floral foam to maintain leaf turgor. Two G. platensis adults (one male and one female) were placed in the middle of the cage, and the number of feeding and contact with leaves events were recorded at $5 \mathrm{~min}$ intervals for $30 \mathrm{~min}$. Forty replicates were used for each host combination. Before each trial, adults were starved for $24 \mathrm{~h}$. Experiments were carried out in room conditions, between 11 am and 4 pm, over several consecutive days. The cylindrical cage was rotated after each replicate to avoid external effects (e.g. light).

\subsection{Statistical analysis}

Differences in $G$. platensis defoliation in the field between Eucalyptus species and years (fixed factors) were tested with Linear Mixed Models (LMM), considering provenance and leaf stage as random factors and trees as subjects. Leaf stage was included as a categorical variable with two levels: trees that had fully transitioned to adult foliage and trees that totally or partially retained juvenile foliage. Eucalyptus species with no evidence of defoliation in the field were excluded from the analysis. Least significant differences (LSD) were used for multiple comparisons. Abundance classes of adults, larvae, and egg capsules were converted as follows: $0=0$ insects; $1=5$ insects; $2=15$ insects; and $3=30$ insects. Mean values were then used to compare between Eucalyptus species using 
non-parametric Kruskal-Wallis tests for the Arouca and Pampilhosa trials independently followed by pairwise comparisons with Mann-Whitney tests. In no-choice tests, G. platensis initial and final weight was compared among Eucalyptus species by Generalized Linear Model (GLM), with Gaussian distribution. Individual trees were considered subsamples nested within species. GLM with gamma distribution was used to test differences in leaf area consumed, and GLM with binomial distribution (alive/dead) was used to test differences in mortality. GLM tests were followed by pairwise comparisons. In choice tests, insect preference was analysed with Wilcoxon signed-rank test. Homoscedasticity and normality were confirmed with Levene and KolmogorovSmirnov tests, respectively, for the LMM test (Zar 1996). All analyses were performed with SPSS statistics package 22.0 (SPSS 2013) with a 5\% $(\alpha=0.05)$ significance level.

\section{Results}

\subsection{Field trials}

Levels of defoliation by the snout beetle differed significantly between Eucalyptus species at both Arouca $\left(F_{12,24}=26.9\right.$; $p<0.001)$ and Pampilhosa $\left(F_{15,29}=63.3 ; p<0.001\right)$. The level of tree defoliation also differed between years at both Arouca $\left(F_{2,2823}=599.5 ; p<0.001\right)$ and Pampilhosa $\left(F_{2,3525}=759.7\right.$; $p<0.001)$. In Arouca, defoliation levels decreased along the 3 years (Fig. 1), with overall mean values of $27.2 \pm 1.0 \%, 13.1$ $\pm 0.7 \%$, and $0.7 \pm 0.1 \%$ for 2012,2013 , and 2014 , respectively. In Pampilhosa, an opposite increasing trend in defoliation levels was found, with mean values of $23.2 \pm 0.9 \%, 35.2 \pm 1.0 \%$, and $66.4 \pm 1.1 \%$ for 2012,2013 , and 2014, respectively. All species in which defoliation occurred at the Pampilhosa site displayed a similar increasing tendency (Fig. 1).

Overall, Eucalyptus species in section Maidenaria were more defoliated than species belonging to any other section. In both trials, E. globulus was the most defoliated species, followed by E. viminalis and E. smithii. When damage by G. platensis was at low-medium intensity, some species within Maidenaria section were less attacked, particularly E. benthamii Maiden \& Cambage and $E$. nitens. However, at high densities, such differences were no longer evident (Fig. 1 and Table 2). All species from subgenus Eucalyptus as well as E. saligna $\mathrm{Sm}$. (section Latoangulatae) displayed low susceptibility to G. platensis, even though E. fraxinoides H.Deane \& Maiden and E. oreades R.T.Baker were moderately defoliated in Pampilhosa in 2014. Eucalyptus regnans was not attacked by G. platensis, whereas $E$. delegatensis R.T.Baker and E. fastigata H.Deane and Maiden were only slightly defoliated (less than $3 \%$ defoliation), even when snout beetle populations caused the highest defoliation values in 2014 in Pampilhosa (Fig. 1 and Table 2).
Insect abundance in the canopies was found to differ significantly between Eucalyptus species in both Arouca $\left(\chi^{2}=90.3\right.$, $\chi^{2}=142.0$, and $\chi^{2}=146.7$ for adult, larva, and egg capsule abundance, respectively; $\mathrm{df}=14 ; p<0.001$ ) and Pampilhosa trials $\left(\chi^{2}=109.4, \chi^{2}=145.9\right.$, and $\chi^{2}=146.8$ for adult, larva, and egg capsule abundance, respectively; $\mathrm{df}=16 ; p<0.001$ ). Five Eucalyptus species consistently hosted the highest numbers of insects of all life stages in both trials, namely E. dunnii, E. smithii, E. macarthurii, E. globulus, and E. viminalis (Fig. 2). Particularly in the Arouca trial, more than 20 egg capsules or 20 larvae were frequently found in canopies of these species. Eucalyptus badjensis, E. bicostata, E. maidenii, and E. dalrympleana were found to host intermediate numbers of $G$. platensis egg capsules and larvae in the Arouca trial, but not in the Pampilhosa trial. Small numbers of insects were found in E. nitens and E. saligna, whereas no insects were found in any of the tree species belonging to subgenus Eucalyptus.

\subsection{No-choice and choice tests}

In no-choice tests, $G$. platensis adult weight at the end of the 2month experiment differed significantly between the five Eucalyptus species tested (Wald $\chi^{2}=122.6$; $\mathrm{df}=4 ; p<0.001$; Table 3). Insect weight was highest for G. platensis fed on E. smithii and E. badjensis leaves, and was lowest for those feeding on E. regnans. Intermediate values were found for $E$. globulus and $E$. nitens. Leaf area consumed by snout beetle adults was also affected by host species (Wald $\chi^{2}=16.8 ; \mathrm{df}=4$; $p<0.01$; Table 3). The amount of leaves consumed was significantly greater on E. badjensis, E. globulus, and E. smithii than on $E$. regnans, while $E$. nitens displayed intermediate levels of leaf consumption. Within the 2-month trial period, adult mortality of $G$. platensis was highest on E. regnans (40\%), intermediate on E. nitens (24\%), and lowest on E. badjensis, E. smithii, and E. globulus (6\% or lower) (Wald $\chi^{2}=46.4 ; \mathrm{df}=4 ; p<0.001$; Table 3).

In choice tests (Fig. 3), G. platensis preferred to feed on E. globulus rather than on $E$. nitens $(U=7.3 ; p<0.001)$ or on E. regnans $(U=10.6 ; p<0.001)$, while $E$ nitens was preferred to $E$. regnans $(U=6.9 ; p<0.001)$. With regard to contact events between $G$. platensis and host plants, no significant difference was found between E. globulus and E. nitens $(U=1.2 ; p=0.22)$, while the frequency of contacts with E. regnans was lower than with either E. globulus or E. nitens (respectively $U=4.6$ and $U=5.6 ; p<0.001$ ).

\section{Discussion}

Gonipterus platensis fed on 16 Eucalyptus species out of the 17 tested, from both subgenera. Within subgenus Eucalyptus, low levels of feeding by G. platensis were typically found, particularly on host species from series Regnantes 

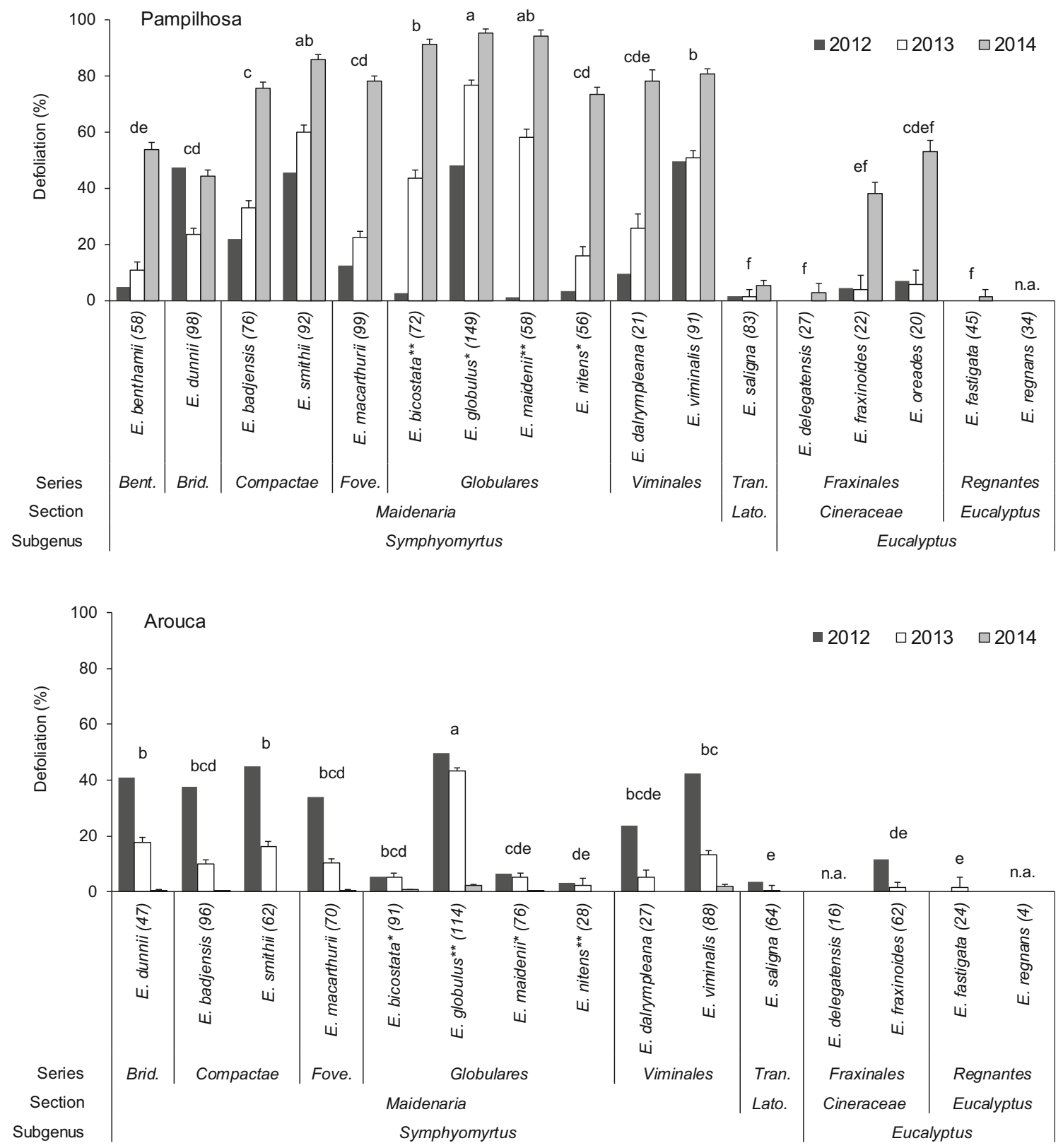

Fig. 1 Defoliation by Gonipterus platensis (mean \pm SE) on 17 Eucalyptus species in the field trials at Pampilhosa da Serra (top) and Arouca (bottom), between 2012 and 2014. The number of sampled trees is indicated in parenthesis. Different letters indicate significant differences between species for each trial (LMM and LSD multiple comparisons, $p<0.05$ ) (Series/section abbreviations: Bent., Benthamianae; Brid., Bridgesianae; Fove., Foveolatae; Tran.,

(E. regnans and E. fastigata) and on E. delegatensis. In this study, E. regnans was found to be an unsuitable host for the snout beetle. Within subgenus Symphyomyrtus, species from section Maidenaria were consistently attacked by G. platensis, although variable levels of defoliation were recorded, while E. saligna (section Latoangulatae) displayed low levels of defoliation. A similar pattern was found in a previous study with G. platensis in Spain (Cordero-Rivera and Santolamazza-Carbone 2000), with most species belonging
Transversae; and Lato., Latoangulatae). Notes: * after species names indicates that, on average, $35.2 \%$ and $7.8 \%$ of trees had not fully transitioned to adult foliage in 2012 and 2013, respectively, underestimating defoliation; ** after species name indicates that, on average, $94.2 \%$ and $65.0 \%$ of the trees had not fully transitioned to adult foliage in 2012 and 2013, respectively, underestimating defoliation

to subgenus Symphyomyrtus being moderately to heavily attacked, with the exception of E. saligna and E. rubida Deane \& Maiden (Table 2). Four species were addressed simultaneously in both the present study and the one by Cordero-Rivera and Santolamazza-Carbone (2000), namely E. globulus, E. fastigata, E. saligna, and E. viminalis, with consistent results (Table 2). Our study thus provides information on 13 additional Eucalyptus species regarding the host range and feeding preference of $G$. platensis. 
Table 2 Damage level by Gonipterus platensis feeding on eucalypt species in two studies: (1) Cordero-Rivera and Santolamazza-Carbone (2000) and (2) present study. Damage level categorized as: 0: no feeding; *: low (first quartile); **: medium (second and third quartiles); and $* * *$ : high (fourth quartile)

\begin{tabular}{|c|c|c|c|c|c|c|}
\hline Genus (subgenus) $^{1}$ & Section $^{2}$ & Series $^{2}$ & Species & (1) & $\begin{array}{l}\text { (2) Low pest } \\
\text { intensity }\end{array}$ & $\begin{array}{l}\text { (2) High pest } \\
\text { intensity }\end{array}$ \\
\hline \multirow[t]{2}{*}{ Corymbia } & Notiales & Disjunctae & $\begin{array}{l}\text { C. ficifolia (F.Muell.) K.D.Hill \& } \\
\text { L.A.S.Johnson }\end{array}$ & 0 & - & - \\
\hline & Septentrionales & Maculatae & $\begin{array}{l}\text { C. citriodora (Hook.) K.D.Hill \& } \\
\text { L.A.S.Johnson }\end{array}$ & $* *$ & - & - \\
\hline \multirow{10}{*}{$\begin{array}{l}\text { Eucalyptus } \\
\quad \text { (Eucalyptus) }\end{array}$} & \multirow[t]{2}{*}{ Aromatica } & Insulanae & E. amygdalina Labill. & 0 & - & - \\
\hline & & Radiatae & E. dives Schauer & $*$ & - & - \\
\hline & \multirow[t]{4}{*}{ Cineraceae } & \multirow[t]{3}{*}{ Fraxinales } & E. delegatensis R.T.Baker & - & $*$ & $*$ \\
\hline & & & E. fraxinoides H.Deane \& Maiden & - & $*$ & $* *$ \\
\hline & & & E. oreades R.T.Baker & - & $*$ & $* *$ \\
\hline & & Pauciflorae & E. pauciflora Spreng. & $* *$ & - & - \\
\hline & \multirow[t]{3}{*}{ Eucalyptus } & Eucalyptus & E. obliqua L'Her. & 0 & - & - \\
\hline & & Regnantes & E. fastigata H.Deane and Maiden & 0 & 0 & $*$ \\
\hline & & & E. regnans F.Muell. & - & 0 & 0 \\
\hline & Pseudophloius & - & E. pilularis $\mathrm{Sm}$. & $*$ & - & - \\
\hline $\begin{array}{l}\text { Eucalyptus } \\
\quad \text { (Nothocalyptus) }\end{array}$ & - & - & E. microcorys F.Muell. & $*$ & - & - \\
\hline \multirow{18}{*}{$\begin{array}{l}\text { Eucalyptus } \\
\quad \text { (Symphyomyrtus) }\end{array}$} & Bisectae & Cornutae & E. cornuta Labill. & 0 & - & - \\
\hline & \multirow[t]{3}{*}{ Latoangulatae } & Lepidotae-Fimbriatae & E. propinqua H.Deane \& Maiden & $* * *$ & - & - \\
\hline & & \multirow[t]{2}{*}{ Transversae } & E. grandis W.Hill & $* * *$ & - & - \\
\hline & & & E. saligna $\mathrm{Sm}$. & $*$ & $*$ & $*$ \\
\hline & \multirow[t]{13}{*}{ Maidenaria } & Benthamianae & E. benthamii Maiden \& Cambage & - & $*$ & $* *$ \\
\hline & & Bridgesianae & E. dunnii Maiden & - & $* *$ & $* *$ \\
\hline & & \multirow[t]{2}{*}{ Compactae } & E. badjensis Beuzev. \& M.B.Welch & - & $* *$ & $* *$ \\
\hline & & & E. smithii R.T.Baker & - & $* *$ & $* * *$ \\
\hline & & \multirow[t]{2}{*}{ Foveolatae } & E. macarthurii H.Deane \& Maiden & - & $* *$ & $* *$ \\
\hline & & & E. ovata Labill. & $* *$ & - & - \\
\hline & & \multirow[t]{4}{*}{ Globulares } & $\begin{array}{l}\text { E. bicostata Maiden, Blakely \& } \\
\text { Simmonds }\end{array}$ & - & $* *$ & $* * *$ \\
\hline & & & E. globulus Labill. & $* * *$ & $* * *$ & $* * *$ \\
\hline & & & E. maidenii F.Muell. & - & $* *$ & $* * *$ \\
\hline & & & E. nitens Maiden & - & $*$ & $* *$ \\
\hline & & \multirow[t]{3}{*}{ Viminales } & E. dalrympleana Maiden & - & $* *$ & $* *$ \\
\hline & & & E. rubida H.Deane \& Maiden & $*$ & - & - \\
\hline & & & E. viminalis Labill. & $* *$ & $* * *$ & $* * *$ \\
\hline & Similares & - & E. longifolia Lindl. & $* * *$ & - & - \\
\hline
\end{tabular}

\footnotetext{
${ }^{1}$ Sensu Hill and Johnson (1995)
}

${ }^{2}$ Sensu Brooker (2000)

The Tasmanian native G. platensis fed on several host species that are native to other parts of Australia, mostly within section Maidenaria. Closely related plants are likely to share traits that make them similarly acceptable to a particular phytophagous insect (Bertheau et al. 2010; Branco et al. 2014a; Östrand et al. 2008) and this seems to hold true for the snout beetle. In South Africa, Newete et al. (2011) found that Gonipterus sp. n. 2 (sensu Mapondera et al. 2012) also preferred to feed on eucalypts from section Maidenaria. In addition, while this Gonipterus species was found to accept some hosts within the Latoangulatae section, namely E. grandis and Eucalyptus propinqua H.Deane \& Maiden, it also displayed low levels of feeding on E. saligna. Similar results were described for G. platensis by CorderoRivera and Santolamazza-Carbone (2000) in Spain. Gonipterus platensis and Gonipterus sp. n. 2 therefore share considerable overlap in host range. Other Gonipterus species display quite a different host range, such as Gonipterus notographus Boisduval (sensu Mapondera et al. 2012), which was found to prefer hosts belonging to subgenus Eucalyptus rather than Symphyomyrtus (Clarke et al. 1998). This is not surprising, as G. platensis and 
Pampilhosa
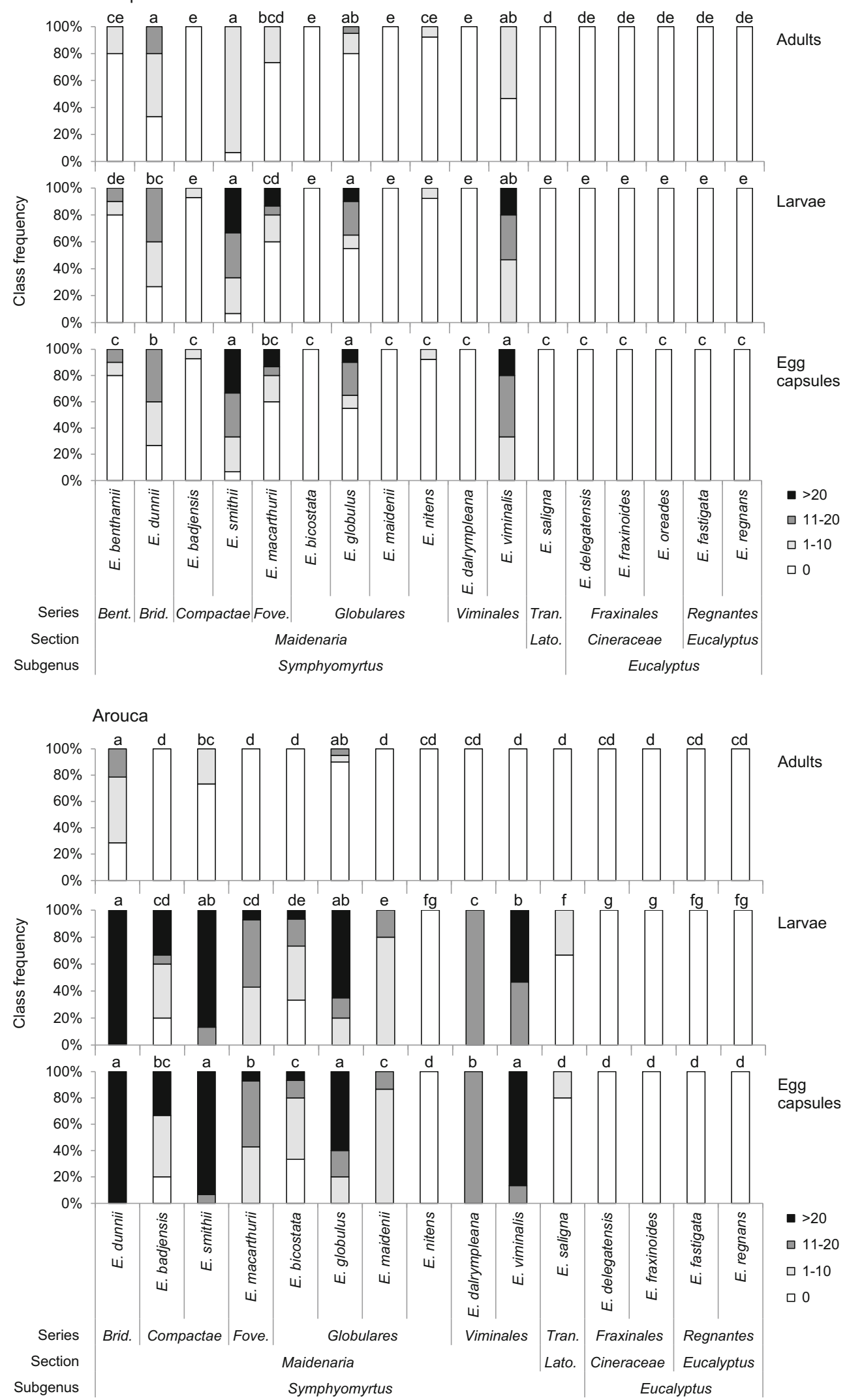

Gonipterus sp. n 2 are related species within the Gonipterus scutellatus Gyllenhal complex, while G. notographus is placed in a sister-group (Mapondera et al. 2012) and related insect species often use related hosts (Morse and Farrell 2005; Winkler and 
Fig. 2 Frequency of Gonipterus platensis abundance classes for egg capsules, larvae, and adults on 17 Eucalyptus species in the field trials at Pampilhosa da Serra (top) and Arouca (bottom), in 2012. Abundance classes used are 0 (no insects); 1-10 (1 to 10 insects); 11-20 (11 to 20 insects); and $>20$ (more than 20 insects). Different letters indicate significant differences between Eucalyptus species for each variable and trial (non-parametric Mann-Whitney $U$ test, $p<0.05$ ). (Series/section abbreviations: Bent., Benthamianae; Brid., Bridgesianae; Fove., Foveolatae; Tran., Transversae; and Lato., Latoangulatae)

Mitter 2008). Nevertheless, considerable differences between G. platensis and Gonipterus sp. n. 2 have been found regarding economically important Eucalyptus species. While G. platensis has been shown to prefer E. globulus over other host species (Cordero-Rivera and Santolamazza-Carbone 2000; Hanks et al. 2000; Lanfranco and Dungey 2001; Tooke 1955), this Eucalyptus species was only moderately attacked by Gonipterus sp. n. 2 (Newete et al. 2011). Inversely, E. nitens was moderately attacked by $G$. platensis while it was one of the species preferred by Gonipterus sp. n. 2.

Semi-field and laboratory tests mostly confirmed the results obtained under field conditions. Traits like pest survival, food consumption, or weight gain were consistently higher in host species preferred under field conditions, such as E. globulus, E. smithii, or E. badjensis, and lower in the least preferred species. However, under experimental conditions, when insects are forced to feed on a particular plant species, they may use hosts that they would normally not use in the field (Newete et al. 2011; Palmer and Goeden 1991). Indeed, in our study, G. platensis never fed on E. regnans whenever an alternative host was accessible, but some consumption occurred in the no-choice test. A similar effect was found under field conditions when pest pressure increased. In the Pampilhosa trial, E. nitens, E. benthamii, $E$. fraxinoides, and $E$. oreades displayed low levels of defoliation when pest pressure was low (2012 and 2013), but defoliation increased disproportionately when pest pressure was high (2014). An increase in the realized host range due to intraspecific competition at high population densities has been observed for other species (Branco et al. 2014b; Castagneyrol et al. 2016; Svanbäck and Bolnick 2007). Under high densities of G. platensis, it seems likely that decreased availability of foliage of the most susceptible hosts due to intense defoliation caused the snout beetle to feed on less preferred species.

Laboratory choice tests against a preferred host such as E. globulus seemed adequate for screening susceptibility to G. platensis and can precede more laborious field testing. One interesting aspect was that the number of contacts with the host plant often did not indicate evidence of host discrimination, suggesting that feeding was induced by physical and/ or chemical cues resulting from direct contact with leaves, as observed in other eucalypt pests (Ohmart et al. 1985; Steinbauer and Matsuki 2004).

Furthermore, during the course of field evaluations, Eucalyptus species in series Globulares were shifting to adult foliage. Differences in the response of herbivorous insects to juvenile and adult leaves within Eucalyptus species are widely recognized (Gosney et al. 2014; Steinbauer 2002). Gonipterus species in particular have been shown to display strong preference for expanding and newly expanded adult leaves (Branco et al. 2016; Loch 2006; Tooke 1955). Therefore, it seems likely that G. platensis defoliation of Eucalyptus species in series Globulares within the first years following plantation may not accurately characterize long-term susceptibility.

\section{Conclusion}

Although G. platensis is currently under biological control by the egg parasitoid $A$. nitens, it still causes severe damage in several regions in Portugal where large E. globulus plantations are located (Reis et al. 2012; Valente et al. 2018). In these regions, Eucalyptus genetic materials less susceptible to G. platensis can be a viable option. Here we tested 16 alternative Eucalyptus species for potential use in forest plantations in the areas most affected by G. platensis. Overall, feeding by the snout beetle was low on species from subgenus Eucalyptus and on E. saligna. Within subgenus Symphyomyrtus, all of the tested species in section Maidenaria were susceptible to G. platensis, even though some may be good alternatives to E. globulus, provided that snout beetle populations are low to moderate.
Table 3 Dry weight, leaf area consumed, and adult mortality (mean \pm SE) by Gonipterus platensis adults kept on sleeved branches with five Eucalyptus species for 2 months (10 replicates per species) in a semi-field no-choice test. Different letters indicate significant differences between host plants (GLM with normal distribution for dry weight; GLM with gamma distribution for leaf area consumed; and GLM with binomial distribution for adult mortality, $p<0.05$; all tests followed by pairwise comparisons)

\begin{tabular}{llll}
\hline Species & Dry weight $(\mathrm{mg})$ & Leaf area consumed $\left(\mathrm{cm}^{2}\right)$ & Adult mortality (frequency) \\
\hline E. badjensis & $27.1 \pm 0.8 \mathrm{a}$ & $62.3 \pm 16.9 \mathrm{a}$ & $0.03 \pm 0.02 \mathrm{c}$ \\
E. globulus & $23.9 \pm 0.6 \mathrm{~b}$ & $48.4 \pm 6.4 \mathrm{ab}$ & $0.06 \pm 0.03 \mathrm{c}$ \\
E. nitens & $23.5 \pm 0.7 \mathrm{~b}$ & $32.6 \pm 5.5 \mathrm{bc}$ & $0.24 \pm 0.05 \mathrm{~b}$ \\
E. regnans & $19.2 \pm 0.5 \mathrm{c}$ & $19.5 \pm 3.3 \mathrm{c}$ & $0.40 \pm 0.06 \mathrm{a}$ \\
E. smithii & $27.8 \pm 0.7 \mathrm{a}$ & $36.3 \pm 6.2 \mathrm{ab}$ & $0.03 \pm 0.02 \mathrm{c}$ \\
\hline
\end{tabular}


Fig. 3 Percentage of contact and feeding events by Gonipterus platensis adults exposed to combinations of three Eucalyptus species in choice tests. Species 1 and Species 2 refer to the first and second species in the combination, respectively (Wilcoxon signed-rank test, * $p<0.001$, ns not significant)

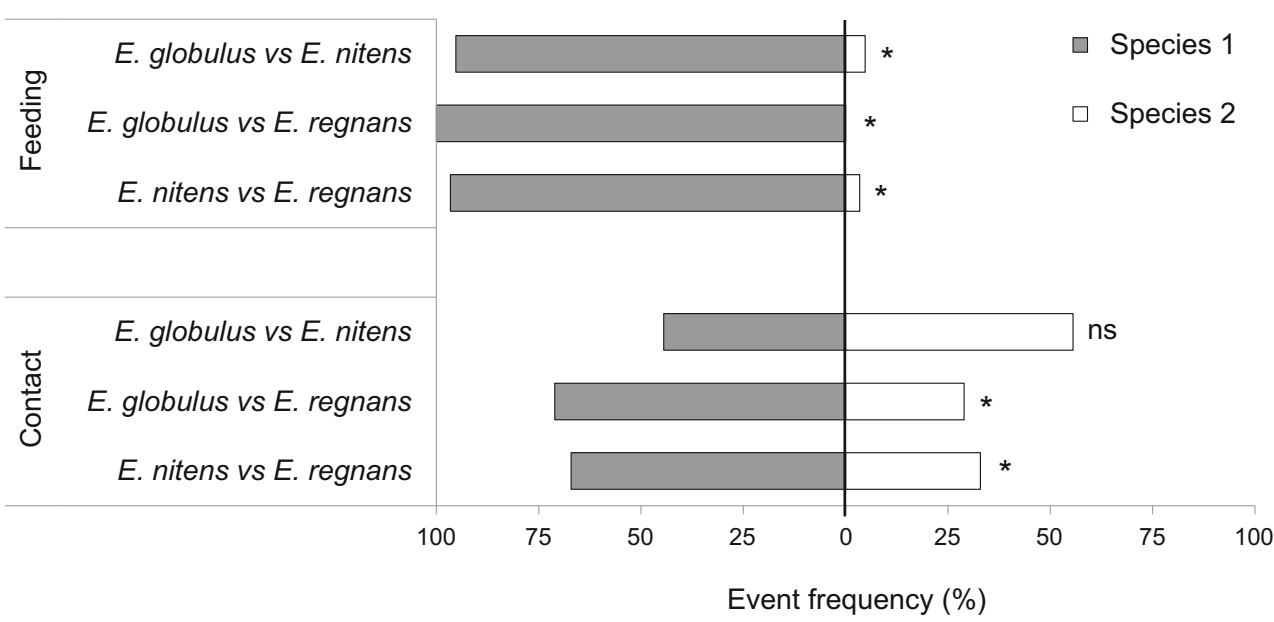

However, before many of these species can be used in commercial plantations, additional information is required on growth and survival under local climatic conditions, and on wood properties for pulping. Moreover, further studies are required on the susceptibility to other pests and diseases, and on how they may affect eucalypt growth in single-species commercial plantations.

Acknowledgements The authors would like to thank Cláudia Ferraz, Fernanda Monteiro, Luís Queirós, José Cardoso, and Rui Gomes for laboratory and field assistance. We are indebted to António Ramos and José Alexandre Araújo for producing the seedlings used in field trials and four anonymous reviewers for valuable comments on the manuscript.

Funding This study was partially funded by projects QREN/5477/PTLYPTUS, Interreg Forrisk SOE3/P2/F523, and by RAIZ. Centro de Estudos Florestais is a research unit funded by Fundação para a Ciência e a Tecnologia I.P. (FCT), Portugal (UID/AGR/00239/2013).

Data availability The datasets generated during and/or analysed during the current study are available from the corresponding author on reasonable request.

\section{Compliance with ethical standards}

Conflict of interest The authors declare that they have no conflict of interest.

\section{References}

Arzone A (1985) Biological control of the Eucalyptus snout beetle in Italy. Bull Sect Reg Ouest Palearct 8:70-73

Bertheau C, Brockerhoff EG, Roux-Morabito G, Lieutier F, Jactel H (2010) Novel insect-tree associations resulting from accidental and intentional biological 'invasions': a meta-analysis of effects on insect fitness. Ecol Lett 13:506-515. https://doi.org/10.1111/j.14610248.2010.01445.x

Branco M, Brockerhoff EG, Castagneyrol B, Orazio C, Jactel H (2014a) Host range expansion of native insects to exotic trees increases with area of introduction and the presence of congeneric native trees. J Appl Ecol 52:69-77. https://doi.org/10.1111/1365-2664.12362
Branco M, Dhahri S, Santos M, Jamaa MLB (2014b) Biological control reduces herbivore's host range. Biol Control 69:59-64. https://doi. org/10.1016/j.biocontrol.2013.11.001

Branco M, Battisti A, Mendel Z (2016) Foliage feeding invasive insects: defoliators and gall makers. In: Paine TD, Lieutier F (eds) Insects and diseases of Mediterranean Forest Systems. Springer, Basel, pp 211-238

Brooker MIH (2000) A new classification of the genus Eucalyptus L'Hér. (Myrtaceae). Aust Syst Bot 13:79-148. https://doi.org/10.1071/ SB98008

Campinhos E (1999) Sustainable plantations of high-yield shape Eucalyptus trees for production of fiber: the Aracruz case. New For 17:129-143. https://doi.org/10.1023/A:1006562225915

Castagneyrol B, Jactel H, Brockerhoff EG, Perrette N, Larter M, Delzon S, Piou D (2016) Host range expansion is density dependent. Oecologia 182:779-788. https://doi.org/10.1007/s00442-0163711-5

Clarke AR, Paterson S, Pennington P (1998) Gonipterus scutellatus Gyllenhal (Coleoptera: Curculionidae) oviposition on seven naturally co-occurring Eucalyptus species. For Ecol Manag 110:89-99. https://doi.org/10.1016/S0378-1127(98)00277-1

Cordero-Rivera A, Santolamazza-Carbone S (2000) The effect of three species of Eucalyptus on growth and fecundity of the Eucalyptus snout beetle (Gonipterus scutellatus). Forestry 73:21-29. https://doi. org/10.1093/forestry/73.1.21

Cordero-Rivera A, Santolamazza-Carbone S, Andrés JA (1999) Life cycle and biological control of the Eucalyptus snout beetle (Coleoptera, Curculionidae) by Anaphes nitens (Hymenoptera, Mymaridae) in north-west Spain. Agric For Entomol 1:103-109. https://doi.org/10.1046/j.1461-9563.1999.00016.x

Costa e Silva J, Borralho NMG, Araújo JA, Vaillancourt RE, Potts BM (2009) Genetic parameters for growth, wood density and pulp yield in Eucalyptus globulus. Tree Genet Genomes 5:291-305. https:// doi.org/10.1007/s11295-008-0174-9

Echeverri-Molina D, Santolamazza-Carbone S (2010) Toxicity of synthetic and biological insecticides against adults of the Eucalyptus snout-beetle Gonipterus scutellatus Gyllenhal (Coleoptera: Curculionidae). J Pest Sci 83:297-305. https://doi.org/10.1007/ s10340-010-0298-1

González-García S, Hospido A, Moreira MT, Romero J, Feijoo G (2009) Environmental impact assessment of total chlorine free pulp from Eucalyptus globulus in Spain. J Clean Prod 17:1010-1016. https:// doi.org/10.1016/j.jclepro.2009.02.017

Gosney BJ, O'Reilly-Wapstra JM, Forster LG, Barbour RC, Iason GR, Potts BM (2014) Genetic and ontogenic variation in an endangered tree structures dependent arthropod and fungal communities. PLoS One 9:e114132. https://doi.org/10.1371/journal.pone.0114132 
Hanks LM, Millar JG, Paine TD, Campbell CD (2000) Classical biological control of the Australian weevil Gonipterus scutellatus (Coleoptera: Curculionidae) in California. Environ Entomol 29: 369-375. https://doi.org/10.1093/ee/29.2.369

Hill KD, Johnson LAS (1995) Systematic studies in the eucalypts. 7. A revision of the bloodwoods, genus Corymbia (Myrtaceae). Telopea 6:185-504. https://doi.org/10.7751/telopea19953017

Huerta-Fuentes A, Chiffelle-Gómez I, Serrano-Garzón M, Vásquez-Silva T, Araya-Clericus J (2008) Susceptibility of eucalyptus species to Gonipterus scutellatus (Coleoptera: Curculionidae) and electrophoretic profiles of adult maker proteins. Agrociencia 42:27-334

ICNF (2013) IFN6 - Áreas dos usos do solo e das espécies florestais de Portugal Continental em 1995, 2005 e 2010. Instituto da Conservação da Natureza e das Florestas. http://www.icnf.pt/ portal/florestas/ifn/resource/ficheiros/ifn/ifn6-res-prelimv1-1. Accessed 12 June 2018

Jactel H, Nicoll BC, Branco M, Gonzalez-Olabarria JR, Grodzki W, Långström B, Moreira F, Netherer S, Orazio C, Piou D, Santos H, Schelhaas MJ, Tojic K, Vodde F (2009) The influences of forest stand management on biotic and abiotic risks of damage. Ann For Sci 66:1-18. https://doi.org/10.1051/forest/2009054

Lanfranco D, Dungey H (2001) Insect damage in Eucalyptus: a review of plantations in Chile. Austral Ecol 26:477-481. https://doi.org/10. 1046/j.1442-9993.2001.01131.x

Lanfranco D, Peredo H, Ruiz C (2011) Forest insects and pathogens invasions in Chile: case studies in Pinus and Eucalyptus plantations. In: Pathogens, insects and their associations affecting forestry worldwide. Proceedings of the IUFRO Protection Joint Meeting, Colonia del Sacramento. https://doi.org/10.13140/2.1.5020.0325

Loch AD (2006) Phenology of Eucalyptus weevil, Gonipterus scutellatus Gyllenhal (Coleoptera: Curculionidae), and chrysomelid beetles in Eucalyptus globulus plantations in south-western Australia. Agric For Entomol 8:155-165. https://doi.org/10.1111/j.1461-9563.2006.00294.x

Loch AD, Matsuki M (2010) Effects of defoliation by Eucalyptus weevil, Gonipterus scutellatus, and chrysomelid beetles on growth of Eucalyptus globulus in southwestern Australia. For Ecol Manag 260:1324-1332. https://doi.org/10.1016/j.foreco.2010.07.025

Mansilla-Vázquez JP, Pérez-Otero R (1996) El defoliador del eucalipto Gonipterus scutellatus. Phytoma España 81:36-42

Mapondera T, Burgess T, Matsuki M, Oberprieler R (2012) Identification and molecular phylogenetics of the cryptic species of the Gonipterus scutellatus complex (Coleoptera: Curculionidae: Gonipterini). Aust J Entomol 51:175-188. https://doi.org/10.1111/j.1440-6055.2011.00853.x

Morse GE, Farrell BD (2005) Ecological and evolutionary diversification of the seed beetle genus Stator (Coleoptera: Chrysomelidae: Bruchinae). Evolution 59:1315-1333. https://doi.org/10.1111/j. 0014-3820.2005.tb01782.x

Newete S, Oberprieler R, Byrne M (2011) The host range of the Eucalyptus weevil, Gonipterus "scutellatus" Gyllenhal (Coleoptera: Curculionidae), in South Africa. Ann For Sci 68: 1005-1013. https://doi.org/10.1007/s13595-011-0108-9

Ohmart CP, Stewart LG, Thomas JR (1985) Effects of food quality, particularly nitrogen concentrations, of Eucalyptus blakelyi foliage on the growth of Paropsis afomaria larvae (Coleoptera: Chrysomelidae). Oecologia 65:543-549. https://doi.org/10.1007/ BF00379670

Östrand F, Wallis IR, Davies NW, Matsuki M, Steinbauer MJ (2008) Causes and consequences of host expansion by Mnesampela privata. J Chem Ecol 34:153-167. https://doi.org/10.1007/s10886007-9422-y

Palmer WA, Goeden RD (1991) The host range of Ophraella communa Lesage (Coleoptera: Chrysomelidae). Coleopt Bull 45:115-120

Reis A, Ferreira L, Tomé M, Araujo C, Branco M (2012) Efficiency of biological control of Gonipterus platensis (Coleoptera:
Curculionidae) by Anaphes nitens (Hymenoptera: Mymaridae) in cold areas of the Iberian Peninsula: implications for defoliation and wood production in Eucalyptus globulus. For Ecol Manag 270:216-222. https://doi.org/10.1016/j.foreco.2012.01.038

Richardson K, Meakins R (1986) Inter and intra-specific variation in the susceptibility of Eucalypts to the snout beetle Gonipterus scutellatus Gyll. (Coleoptera: Curculionidae). S Afr For J 139:21-31. https:// doi.org/10.1080/00382167.1986.9630053

SECF (2010) Situación de los bosques y del sector forestal en España. Informe 2010. Sociedad Española de Ciencias Florestales, Palencia

Sousa EMR, Ferreira LJC (1996) Gonipterus scutellatus Gyll., uma nova praga do eucalipto em Portugal. Rev Florestal 9:4-7

Steinbauer MJ (2002) Oviposition preference and neonate performance of Mnesampela privata in relation to heterophylly in Eucalyptus dunnii and E. globulus. Agric For Entomol 4:245-253. https://doi. org/10.1046/j.1461-9563.2002.00151.x

Steinbauer MJ, Matsuki M (2004) Suitability of Eucalyptus and Corymbia for Mnesampela privata (Guenée) (Lepidoptera: Geometridae) larvae. Agric For Entomol 6:323-332. https://doi. org/10.1111/j.1461-9555.2004.00238.x

Stone C, Matsuki M, Carnegie A (2003) In: Parsons M (ed) Pest and disease assessment in young eucalypt plantations: field manual for using the Crown Damage Index. National Forest Inventory, Bureau of Rural Sciences, Canberra

Svanbäck R, Bolnick DI (2007) Intraspecific competition drives increased resource use diversity within a natural population. Proc R Soc B 274:839-844. https://doi.org/10.1098/rspb.2006.0198

Tooke F (1955) The Eucalyptus snout beetle, Gonipterus scutellatus Gyll. A study of its ecology and control by biological means. In: Entomological Memoirs. Department of Agriculture, Pretoria

Tribe GD (2005) The present status of Anaphes nitens (Hymenoptera: Mymaridae), an egg parasitoid of the Eucalyptus snout beetle Gonipterus scutellatus, in the Western Cape Province of South Africa. S Afr For J 203:49-54. https://doi.org/10.2989/ 10295920509505218

Valente C, Gonçalves CI, Reis A, Branco M (2017) Pre-selection and biological potential of the egg parasitoid Anaphes inexpectatus for the control of the Eucalyptus snout beetle, Gonipterus platensis. J Pest Sci 90:811-923. https://doi.org/10.1007/s10340-017-0839-y

Valente C, Gonçalves CI, Monteiro F, Gaspar J, Silva M, Sottomayor M, Paiva MR, Branco M (2018) Economic outcome of classical biological control: a case study on the Eucalyptus snout beetle, Gonipterus platensis, and the parasitoid Anaphes nitens. Ecol Econ 149:40-47. https://doi.org/10.1016/j.ecolecon.2018.03.001

Wingfield MJ, Slippers B, Hurley BP, Coutinho T, Wingfield BD, Roux J (2008) Eucalypt pests and diseases: growing threats to plantation productivity. South For 70:139-144. https://doi.org/10.2989/ SOUTH.FOR.2008.70.2.9.537

Winkler IS, Mitter C (2008) The phylogenetic dimension of insect-plant interactions: a review of recent evidence. In: Tilmon KJ (ed) Specialization, speciation, and radiation: the evolutionary biology of herbivorous insects. University of California Press, Berkeley, pp 240-263

Zar JH (1996) Biostatistical analysis, 3rd edn. Prentice Hall, Upper Saddle River

Publisher's note Springer Nature remains neutral with regard to jurisdictional claims in published maps and institutional affiliations. 